\title{
PRASANGKA SOSIAL DALAM PLURALITAS KEBERAGAMAAN DI KECAMATAN CIGUGUR KABUPATEN KUNINGAN JAWA BARAT
}

\author{
Wawan Hernawan
}

Program Studi Ilmu Komunikasi Fakultas Ilmu Sosial dan Ilmu Politik Universitas Bandar Lampung Email : Wawangahara@yahoo.co.id

\begin{abstract}
ABSTRAK. Penelitian ini bertujuan untuk mengungkap lebih mendalam tentang prasangka sosial dalam pluralitas keberagamaan dan upaya meminimalisasi prasangka sosial tersebut sebagai upaya mewujudkan kerukunan hidup dalam pluralitas keberagamaan dari perspektif ilmu komunikasi. Penelitian ini menggunakan pendekatan kualitatif. Penelitian dengan menggunakan pendekatan kualitatif berupaya memusatkan perhatian studinya pada realita sebagai produk pikir manusia dengan segala bentuk subyektivitas, emosi dan nilai-nilai yang dianutnya. Melalui pendekatan kualitatif, diharapkan dapat terungkap gambaran mengenai aktualitas, realitas sosial dan persepsi sasaran penelitian yakni prasangka sosial dalam pluralitas keberagamaan. Hasil penelitian menunjukkan bahwa prasangka sosial dalam pluralitas keberagamaan terjadi karena kurangnya informasi individu ataupun kelompok dalam memahami berbagai peristiwa keagamaan yang terjadi di wilayahnya dan adanya kekhawatiran akan penguasaan suatu kelompok keagamaan terhadap kelompok keagamaan lainnya. Prasangka sosial yang berkembang antarkelompok keagamaan dapat diminimalisasi melalui pengembangan sikap saling menghargai/ toleransi, pengendalian diri, tanggung jawab bersama dalam kegiatan sosial kemasyarakatan dan melalui kerja sama yang saling menguntungkan sehingga konflik secara terbuka antarkelompok keagamaan di Kecamatan Cigugur dapat dihindarkan.
\end{abstract}

Kata kunci: prasangka sosial, pluralitas, keberagamaan

\section{SOCIAL PREJUDICE IN RELIGIOUS PLURALITY AT CIGUGUR DISTRICT REGENCY OF KUNINGAN WEST JAVA}

\begin{abstract}
This research is aimed to uncover about social prejudices in religious plurality and certain eforts to decrease social prejudices in order to create harmony in religious plurality in communication major perspective. This research used qualitative approach. Qualitative research is aimed to focusing it's attention in reality as a product of human thought with every subjectvity, emotion, and values within. Through this approach, researcher expect to uncover about actuality, social reality and perception of research target about social prejudice in religious plurality. The outcome of this research shows that social prejudice in religious plurality occur because of lack of information both as individuals or groups in order to understand any kind of religiousity phenomena in their region. Social prejudices in religious plurality is occur because of social anxiety about the dominance of one group to other religion groups through: 1) Dominating strategic terrain, 2) Developing liturgy infrastructure, 3) Developing religion based education, 4) Dominating economic sector, 5) Dominating some strategic incumbent in society, and 6) Conversion. Social prejudice developed in some religious groups toward other other religious groups could be decreased by developing tolerance, self control, help each other, responsibility in social activity and mutual teamwork so social groups conclict in Cigugur could be avoided.
\end{abstract}

Key word: Social prejudice, religious plurality, religious groups

\section{PENDAHULUAN}

Bangsa Indonesia merupakan bangsa yang dibangun dalam pluralitas keberagamaan, yang selain merupakan unsur kekayaan rohaniah yang dapat memperkokoh kehidupan nasional (faktor integratif), juga sekaligus menyimpan potensi konflik (faktor disintegratif). yang sangat dalam akibatnya dan sangat luas implikasinya. Hal ini disebabkan oleh keberadaan agama tidak mengenal batas-batas sosiologis, demografis maupun geografis. "Meskipun berbagai kelompok budaya (ras, suku, agama) saling berinteraksi, tidak secara otomatis saling pengertian terbentuk di antara mereka" (Mulyana, 2001:12). Kondisi demikian, meminjam istilah Goddard (2000:5) "karena adanya penilaian dengan menggunakan standar ganda", yakni suatu komunikasi yang ditandai dengan retorika kami yang benar dan mereka yang salah; memandang dan menilai suatu komunitas tertentu dengan menggunakan acuan norma kelompok/ golongannya sendiri. Penilaian standar ganda tersebut tidak terlepas dari persepsi yang terbentuk pada diri mereka dalam pluralitas keberagamaan.

Persepsi merupakan pandangan atau pengertian seseorang mengenai suatu obyek yang dibentuk melalui suatu proses kognitif berdasarkan informasi tentang obyek yang bersangkutan yang diterima baik melalui penglihatan, pendengaran, penghayatan, perasaan, maupun penciuman. Apa yang dipersepsikan oleh seseorang merupakan realita informasi yang diterimanya yang akan mempengaruhi responnya terhadap obyek yang dipersepsikannya. Persepsi sosial adalah proses 
menangkap arti obyek-obyek sosial dan kejadiankejadian yang kita alami dalam lingkungan kita. Manusia bersifat emosional, sehingga penilaian mereka mengandung resiko (Mulyana, 2002:175). "Persepsi sosial seseorang sangat tergantung dari pengalaman, seleksi dan evaluasi orang yang bersangkutan" (Purwasito, 2003: 173). Persepsi tersebut muncul karena setiap penilaian dan seleksi seseorang terhadap orang lain diukur berdasarkan standar budayanya sendiri. Sedangkan budaya asing yang dicurigai berpengaruh negatif sering ditentukan sebagai upaya merusak budayanya sendiri. Kondisi demikian memungkinkan suatu kelompok budaya tertentu, termasuk kelompok keagamaan berusaha untuk melindungi kebudayaannya dari ketergusuran budaya lain yang dianggapnya merusak. Sehubungan dengan hal tersebut, Mulyana ( 2002:197) menungkapkan "persepsi itu terikat oleh budaya (culture-bound). Bagaimana kita memaknai suatu pesan, obyek, atau lingkungan bergantung pada sistem nilai yang kita anut". Dengan demikian, dalam pluralitas keberagamaan, persepsi seseorang yang menganut agama tertentu terhadap orang yang berbeda agama dengannya akan dipengaruhi oleh pengalaman masa lalunya dan penilaiannya tentang kehidupan beragama. Persepsi tentang sesuatu menyangkut prosesproses tansaksional antara si perseptor dengan obyek yang dipersepsinya. Persepsi seseorang atas obyek yang dipersepsinya akan menimbulkan bagaimana sikap orang tersebut terhadap obyek yang dipersepsinya. Sikap demikian merupakan suatu prasangka.

Mar'at (1981:113) mengungkapkan bahwa "prasangka merupakan dugaan-dugaan yang memiliki nilai ke arah negatif; namun dapat pula dugaan ini bersifat positif. Tetapi pada umumnya mengarah pada penilaian negatif yang diwarnai oleh perasaan yang muncul sesaat itu". Prasangka merupakan pernyataan-pernyataan umum yang didasarkan atas beberapa pengalaman dangkal yang tidak teruji. Karenanya, prasangka merupakan penilaian secara emosional dan cenderung menghakimi pihak lain secara negatif. Dengan demikian, sikap prasangka terhadap orang lain atau kelompok lain merupakan kecenderungan sikap untuk menjauhi dan mengambil jarak serta tidak berhubungan secara erat dengan orang lain atau kelompok lain, juga merupakan kecenderungan untuk merugikan dan tidak membantu orang lain atau kelompok lain. "Efek dari prasangka adalah menjadikan orang lain sebagai sasaran prasangka; misalnya mengkambinghitamkan mereka melalui stereotipe, diskriminasi, dan penciptaan jarak sosial" (Liliweri, 2003:15-16). Prasangka mengandung motif-motif kecurigaan yang lahir dari subyektivitas individu maupun kelompok terhadap kelompok lain yang biasanya ditandai dengan rasa superioritas dari kelompok mayoritas yang memandang inferior terhadap kelompok minoritas. Dengan demikian, adanya sikap prasangka sosial akan menjadi sumber yang potensial bagi perpecahan/disintegrasi yang dapat mengakibatkan terjadinya konflik. Ketika kondisi demikian terjadi, maka akan terjadi pula kemandegan komunikasi sosial budaya antarkelompok, ras, etnik ataupun golongan. Dengan kata lain, prasangka menjadi sumber potensial disharmonisasi dan disintegrasi. Disharmonisasi dan disintegrasi dalam perspektif ini muncul karena adanya kesenjangan informasi serta sikap sinis dan persaingan yang didasarkan bukan atas prestasi melainkan pada rasa kalah dan tidak percaya diri. Dalam hal demikian, prasangka akan menjadi jarak sosial antara berbagai kelompok dalam masyarakat yang cenderung tidak adaptif, tidak fleksibel, bersikap tertutup dan keengganan untuk membuka diri karena berbagai alasan yang tidak rasional.

Dalam kehidupan bermasyarakat dengan pluralitas keberagamaan, persepsi individu atau kelompok keagamaan terhadap kelompok keagamaan lainnya akan membentuk prasangka-prasangka sosial. Jika persepsi individu atau kelompok keagamaan terhadap kelompok keagamaan lainnya positifmaka akan terbentuk hubungan yang harmonis, yakni adanya kebebasan menjalankan syariat agamanya masing-masing, saling menghormati antarkelompok keagamaan, saling mempercayai bahwa aktivitas individu atau kelompok keagamaan yang satu tidak dipandang sebagai ancaman bagi individu atau kelompok keagamaan lainnya, serta dapat terbentuk kerja sama dalam bidang sosial kemasyarakatan antarindividu maupun kelompok keagamaan lainnya bagi tercapainya tujuan masing-masing individu atau kelompok keagamaan. Sebaliknya, jika persepsi individu atau kelompok keagamaan terhadap kelompok keagamaan lainnya negatif, maka kondisi demikian merupakan suatu hal yang potensial bagi munculnya konflik antarkelompok keagamaan. Melalui komunikasi, manusia lebih mampu memahami berbagai faktor yang menjadi penyebab munculnya konflik. "Hanya melalui pemahaman yang mendalam akan sumber-sumber yang menyebabkannya, maka konflik-konflik sosial diantara sesama bangsa Indonesia dapat kita hindarkan atau kita jinakkan" (Nasikun, 1995:5). Karenanya, mozaik budaya itu sungguh perlu dipahami dan dimanfaatkan untuk dijadikan pilar-pilar kekuatan dan ketangguhan nasional" (Lutan, 2001:58).

Pada dasarnya makna terpenting dari terwujudnya keharonisan hidup dalam pluralitas keberagamaan merupakan indikasi kokohnya sikap saling percaya mempercayai antara sesama masyarakat yang mempunyai latar belakang keimanan yang berlainan. Dengan terbentuknya sikap saling mempercayai itu, akan tercipta kondisi yang saling menguntungkan untuk mewujudkan kerja sama seluruh lapisan dan golongan dalam 
segala aspek kehidupan sosial kemasyarakatan untuk mencapai tujuan pembangunan nasional. Sebaliknya, ketidakharmonisan dalam pluralitas keberagamaan merupakan indikasi dari adanya suasana kehidupan yang diliputi oleh prasangka sosial antaranggota/ kelompok masyarakat. Suasana yang demikian ini sewaktu-waktu dapat menimbulkan konflik yang dapat dengan mudah bereskalasi menjadi huru-hara. Ketika kondisi ini muncul ke permukaan, peran para pemuka agama yang sangat penting adalah bagaimana mengajarkan pengendalian diri dan menegakkan moral agama, menumbuhkan toleransi dan sikap bertanggung jawab.

Dengan meminimalisasi prasangka-prasangka negatif, diharapkan dapat terbentuk adanya sikap saling percaya dan saling menghormati antakelompok keagamaan sebagai bangsa yang berbudaya dalam rangka memperkokoh hidup berdampingan secara damai, dapat menerima perbedaan budaya sebagai berkah daripada bencana, dan melakukan upaya damai dengan mereduksi perilaku agresif, serta mencegah terjadinya konflik yang dapat merusak peradaban dengan cara menciptakan forum-forum dialog untuk mencapai kesepahaman. Lembaga Conflict Research Conscortium, University of Colorado, USA, dalam uraiannya bertema Peace, Culture and Society (Liliweri, 2003:38) mengemukakan betapa pentingnya peranan komunikasi untuk membatasi atau mengurangi kesalahpahaman sebagai akibat dari munculnya prasangka sosial negatif.

Berdasarkanuraian diatas, prasangka sosial dalam pluralitas keberagamaan merupakan suatu masalah yang menarik untuk diteliti lebih lanjut. Ketertarikan penulis untuk meneliti hal tersebut dilandasi oleh pengamatan awal di Kecamatan Cigugur Kabupaten Kuningan Jawa Barat dengan komunitas keagamaan yang cukup beragam. Sebagaimana dikemukakan di atas bahwa pluralitas keberagamaan merupakan suatu hal yang potensial bagi terbentuknya prasangka-prasangka sosial negatif yang dapat mengarah pada terjadinya konflik. Namun di daerah tersebut tidak cukup nampak adanya konflik antarkelompok keagamaan. Apakah konflik tersebut memang tidak ada, ataukah ada tapi tidak muncul ke permukaan? Apakah terdapat prasangkaprasangka sosial antarkelompok keagamaan? Jika terdapat prasangka sosial antarkelompok keagamaan, apakah prasangka sosial tersebut dapat menimbulkan konflik? Bagaimanakah meminimalisasi prasangka sosial tersebut sebagai upaya mewujudkan kerukunan hidup dalam pluralitas keberagamaan, merupakan suatu hal yang menarik perhatian penulis untuk melakukan penelitian lebih lanjut. Ketertarikan tersebut, penulis tuangkan dalam penelitian dengan mengangkat tema sentral "Prasangka Sosial dalam Pluralitas Keberagamaan di Kecamatan Cigugur Kabupaten Kuningan Jawa Barat".

Penelitian ini bertujuan untuk mengungkap lebih mendalam tentang prasangka-prasangka sosial dalam pluralitas keberagamaan serta mengungkap lebih mendalam tentang upaya-upaya meminimalisasi prasangka sosial tersebut sebagai upaya mewujudkan kerukunan hidup dalam pluralitas keberagamaan dari perspektif ilmu komunikasi. Istilah prasangka sering digunakan untuk menyatakan sikap-sikap yang apriori, suatu pernyataan sikap yang buruk atau negatif terhadap individu atau kelompok lain. "Dengan demikian, prasangka merupakan sikap yang tidak baik dan dapat dipandang sebagai suatu predisposisi untuk mempersepsi, berpikir, merasa dan bertindak dengan cara-cara yang menentang atau menjauhi dan bukan menyokong atau mendukung" (Newcomb at.al., 1985:564). "Prasangka adalah cara pandang atau perilaku seseorang terhadap orang lain secara negatif' (Purwasito, 2003:178). Liliweri (2003:15) mengungkapkan bahwa "prasangka adalah sikap antipati yang didasarkan pada kesalahan generalisasi atau generalisasi tidak luwes yang diekspresikan sebagai perasaan".

Terdapat tiga hipotesis yang menjadi penyebab terjadinya prasangka, yakni: "1) Adanya ketegangan situasi yang senantiasa relatif dan bersifat individual atau kelompok sentris; 2) Dalam tiap-tiap kelompok akan senantiasa ada minoritas. 3) Adanya persaingan yang mengakibatkan timbulnya prasangka" (Mar'at, 1981:114). Dalam hubungannya dengan kelompok mayoritas dan kelompok minoritas, timbulnya sikap prasangka banyak ditentukan oleh faktor-faktor sebagai berikut:

1) Kekuatan faktual yang terlihat hubungan antara mayoritas dan minoritas.

2) Fakta akan perlakuan terhadap kelompok mayoritas dan minoritas.

3) Fakta mengenai kesempatan untuk usaha pada mayoritas dan minoritas.

4) Fakta mengenai unsur geografik, dimana keluarga minoritas menduduki daerah-daerah tertentu.

5) Posisi dan peran dari sosial ekonomi yang pada umumnya dikuasai oleh kelompok minoritas.

6) Potensi energi eksistensi dari kelompok minoritas dalam mempertahankan kehidupannya. (Mar'at, 1981:115).

Berdasarkan uraian di atas maka dapat digambarkan kerangka penelitian sebagai berikut: 


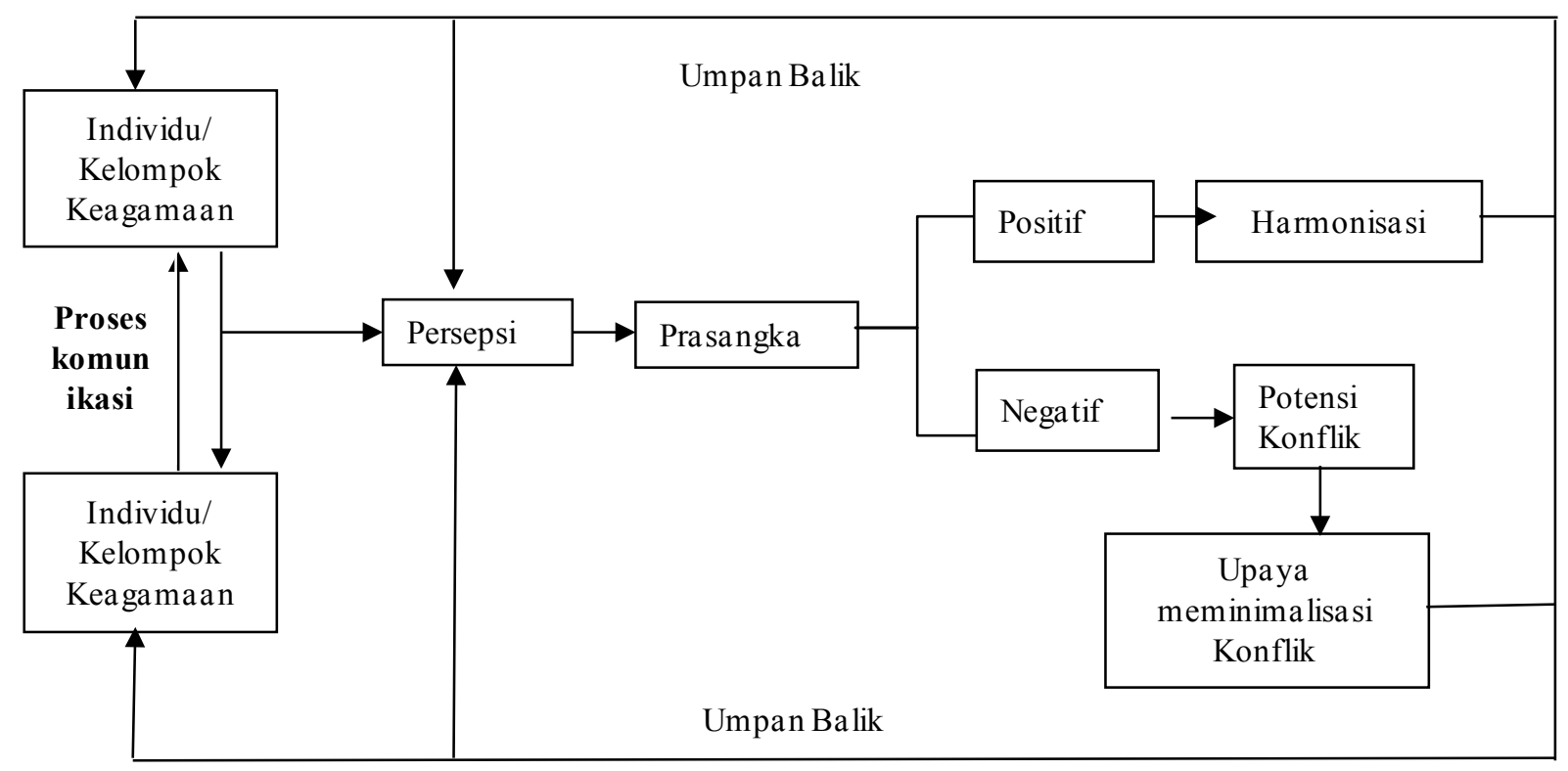

Gambar 1. Kerangka Pikir Penelitian Prasangka Sosial dalam Pluralitas Keberagamaan di Kecamatan Cigugur Kabupaten Kuningan Jawa Barat.

\section{METODE}

Penelitian ini dimaksudkan untuk memahami perilaku manusia dari kerangka acuan si pelaku itu sendiri; yakni bagaimana si pelaku memandang dan menafsirkan kegiatan dari segi kesendiriannya yang biasa disebut persepsi emik. Dalam hal ini, peneliti berusaha memahami dan menggambarkan apa yang dipahami dan digambarkan oleh subyek penelitian. Untuk maksud tersebut, peneliti menggunakan pendekatan kualitatif. Penelitian dengan menggunakan pendekatan kualitatif berupaya memusatkan perhatian studinya pada realita sebagai produk pikir manusia dengan segala bentuk subyektivitas, emosi dan nilai-nilai yang dianutnya. Melalui pendekatan kualitatif, diharapkan dapat terungkap gambaran mengenai aktualitas, realitas sosial dan persepsi sasaran yakni prasangka sosial dalam pluralitas keberagamaan. Teknik penelitian dilakukan melalui pengungkapan banyak cerita yang bersifat idiosinkretis namun penting, tentang peristiwa-peristiwa nyata dengan cara-cara yang alamiah. Karenanya, dalam penelitian ini sangat diperlukan keterlibatan peneliti secara langsung, namun tanpa melakukan intervensi terhadap proses yang sedang berlangsung; apa adanya.

Penelitian kualitatifmenuntut peneliti berhubungan secara langsung dengan sumber data dan menelaah dengan cermat dan seksama perilaku, tempat dan waktu mereka berperilaku. Sumber informasi dalam hal ini pada umumnya adalah orang yang sedang dipelajari atau sekelompok orang yang sedang melakukan aktivitas dalam suatu kondisi. Selain itu, sumber informasi dapat pula bukan manusia seperti obyek, waktu dan lingkungan tertentu. Peneliti seringkali tidak dapat secara langsung berhadapan dengan sumber informasi yang begitu luas dan besar jumlahnya, karenanya dipilih informan penelitian. Dalam penelitian ini informan yang dipilih berdasarkan pertimbangan bahwa orang tersebutmemahami situasi dan kondisi latar penelitian. Penentuan informan dilakukan secara purposif dengan mempertimbangkan pemahaman mereka terhadap permasalahan yang sedang diteliti serta peranannya di dalam masyarakat. Cara menetapkan informan pertama adalah melalui pengamatan terhadap interaksi dan komunikasi yang berlangsung di masyarakat dengan memfokuskan pada karakteristik seseorang yang menonjol dalam kegiatan sosial kemasyarakatan. Setelah diperoleh satu informan pertama, informan selanjutnya ditentukan dengan menggunakan teknik snowball untuk memperoleh berbagai keterangan yang diperlukan sehubungan dengan fokus penelitian. Melalui teknik snowball, informan berikutnya berdasarkan rekomendasi dari informan sebelumnya.

Penentuan informan pada prinsipnya adalah mereka yang berdomisili di desa-desa yang memiliki heterogenitas pemelukan keagamaan di Kecamatan Cigugur, yakni Kelurahan Cigugur, Desa Cisantana, dan Kelurahan Sukamulya sehingga mereka memahami benar tentang berbagai peristiwa kehidupan keagamaan. Penetapan informan secara spesifik memperhatikan faktor usia, posisi dan peran di dalam masyarakat yakni keterlibatan dalam berbagai aktivitas sosial kemasyarakatan, serta agama yang dianut oleh informan yang bersangkutan. Pengelompokan terhadap kecenderungan penguasaan informasi oleh informan ini tidak bersifat mutlak. Hal tersebut dimaksudkan karena tidak menutup kemungkinan terdapat informan yang memahami beberapa jenis informasi atau bahkan semua informasi yang berhubungan dengan fokus penelitian. Namun demikian, sifat informasi yang disampaikannya dapat dipisahkan dalam kecenderungan tertentu.

Pengelompokan informan dalam suatu karakteristik tertentu tetap merujuk pada prinsip-prinsip penelitian kualitatif. Pengelompokan tersebut tidak 
dimaksudkan merujuk pada jumlah atau banyaknya informan, melainkan lebih merujuk kepada karakteristik informasi yang disampaikan kepada peneliti sesuai dengan fokus penelitian. Dalam penelitian ini jumlah informan sebanyak 63 orang. Jumlah tersebut tidak dimaksudkan pada keterwakilan subyek penelitian, melainkan lebih merujuk pada kecukupan informasi yang diperoleh sesuai dengan prinsip penelitian kualitatif. Dari informan yang ada tersebut dapat dikategorikan pada usia, jenis kelamin, tingkat pendidikan, pekerjaan, posisi di dalam masyarakat yang meliputi: pemuka agama Islam dan Katolik), tokoh masyarakat (Islam dan Katolik), pemuka aliran kepercayaan, tokoh pemuda (Islam dan Katolik), dan mualif (orang yang masuk ke agama Islam), serta jenis informasi yang dikuasainya.

Langkah-langkah penelitian yang dilakukan dibagi dalam tiga tahap, yaitu: (1) tahap orientasi lapangan, (2) tahap pengumpulan data, dan (3) tahap member check. Tujuan dari orientasi dalam penelitian kualitatif untuk memperoleh gambaran yang lengkap dan jelas mengenai masalah yang akan diteliti. Kegiatan ini dimulai dari penjajagan lapangan untuk menentukan permasalahan atau fokus penelitian. Pengumpulan data dilakukan melalui: (1) observasi , (2) wawancara, dan (3) dokumentasi. Dalam pengumpulan data, peneliti mengggunakan pribadi peneliti sendiri sebagai alat pengumpul data utama. Teknik observasi yang digunakan dalam penelitian ini adalah participant observation dan participant as observer. Dalam hal ini peneliti dapat memberitahukan maksud kehadiran peneliti ataupun tidak memberitahukan kehadiran peneliti akan sangat tergantung kepada jenis data yang ingin diperoleh. Namun demikian diupayakan agar kehadiran peneliti tidak mengganggu komunitas subyek yang diteliti sehingga dapat diperoleh keterangan yang terinci dan mendalam mengenai pandangan subyek yang diteliti dan subyek yang diteliti tidak akan memanipulasi perilakunya.

Teknik wawancara yang digunakan dalam penelitian ini adalah teknik wawancara tak terstruktur. Teknik wawancara tak terstruktur ini terdiri dari dua teknik yakni wawancara terarah dan wawancara tidak terarah. Wawancara tidak terarah dilakukan agar subyek penelitian memperoleh kebebasan dan kesempatan mengeluarkan pikiran, pandangan, dan perasaannya tanpa diatur ketat oleh peneliti. Teknik ini dilakukan agar peneliti memperoleh keterangan yang lengkap dan mendalam mengenai pandangan subyek yang diteliti. Wawancara jenis ini lebih banyak digunakan pada tahap awal penelitian. Hasil wawancara tidak terarah ini merupakan informasi emic, yaitu informasi berdasarkan pandangan subyek yang diteliti. Selanjutnya informasi emic ini disusun secara bertahap oleh peneliti dalam bentuk wawancara terarah agar wawancara bersifat etic, yakni pandangan peneliti setelah mengolah, menafsirkan, dan menganalisis informasi emic. Data dokumentasi dalam penelitian ini dipergunakan sebagai data pelengkap yang diperoleh baik melalui wawancara maupun observasi.

Member check dilakukan dengan tujuan untuk mengontrol data yang dikumpulkan agar keabsahan data tersebut dapat dipercaya kebenarannya. Data yang dikumpulkan harus diakui kebenarannya oleh sumber informasi dan dibenarkan oleh informan lainnya. Dalam pengecekan keabsahan data tersebut, dilakukan hal-hal sebagai berikut:

a. Hasil wawancara yang telah ditulis dikonfirmasikan kembali kepada semua nara sumber dalam penelitian yang telah dilakukan.

b. Hasil observasi yang telah dicatat minta dikoreksi kembali oleh nara sumber.

c. Melakukan triangulasi kepada para nara sumber.

Pada tahap member check semua hasil pengamatan dan wawancara serta studi dokumentasi yang telah terkumpul yang penganalisisannya dilakukan sejak awal pengumpulan data, dituangkan dalam bentuk rangkuman selanjutnya didiskusikan kembali dengan sumber-sumber data untuk dicek lagi kebenarannya. Pada tahap akhir penelitian ini, dilakukan pengujian terhadap kredibilitas hasil penelitian dengan cara mendiskusikannya baik dengan para ahli/pakar maupun dengan rekan sejawat.

Data yang diperoleh dalam penelitian kualitatif bersifat kualitatis sehingga analisisnya digunakan pula teknik analisis kualitatif. Analisis data dalam penelitian kualitatif dilakukan bersamaan dengan dan setelah pengumpulan data melalui pengorganisasian data dengan cara memilih dan mengelompokkan data berdasarkan klasifikasi data. Analisis data dalam penelitian kualitatif sebagaimana dikemukakan oleh Miles dan Huberman (1992:15-16) dilakukan melalui proses: 1) Reduksi data sebagai proses pemilihan, pemusatan perhatian pada penyederhanaan, pengasbtrakan dan transformasi data kasar yang muncul dari catatan-catatan lapangan. 2) Penyajian data sebagai sekumpulan informasi tersusun yangmemberikemungkinanadanyapenarikankesimpulan dan pengambilan tindakan. 3) Menarik kesimpulan atau verifikasi. Langkah-langkah analisis data tersebut bersifat interaktif. Setelah data yang diperoleh dianalisis, maka hasil temuan yang diperoleh dapat diukur tingkat kepercayaan (validitas) dan keterandalannya (reliabilitas) dengan menggunakan kriteria: 1) Kredibilitas; 2) Transferabilitas; 3) Dependabilitas; dan 4) Konfirmabilitas (Moleong, 1990:173. Secara ringkas analisis data dalam penelitian ini dilakukan dengan mereduksi semua catatan lapangan, menyajikan data dalam bentuk deskripsi sesuai dengan keadaan di lapangan, dan menarik kesimpulan. Dengan demikian analisis data bersifat menyeluruh. Pola analisis ini berlangsung terus-menerus selama penelitian di lapangan berlangsung. 


\section{HASIL DAN PEMBAHASAN}

Prasangka merupakan pernyataan-pernyataan umum yang didasarkan atas beberapa pengalaman dangkal yang tidak teruji. Karenanya, prasangka merupakan penilaian secara emosional dan cenderung menghakimi pihak lain secara negatif. Prasangka mengandung motif-motif kecurigaan yang lahir dari subyektivitas individu maupun kelompok terhadap kelompok lain yang biasanya ditandai dengan rasa superioritas dari kelompok mayoritas yang memandang inferior terhadap kelompok minoritas. Dengan demikian, adanya sikap prasangka sosial akan menjadi sumber yang potensial bagi perpecahan yang dapat mengakibatkan terjadinya konflik. "Prasangka merupakan sikap yang tidak baik dan dapat dipandang sebagai suatu predisposisi untuk mempersepsi, berpikir, merasa dan bertindak dengan cara-cara yang menentang atau menjauhi dan bukan menyokong atau mendukung" (Newcomb et.al., 1985:564). Mar'at (1981:113) mengungkapkan bahwa "prasangka merupakan dugaan-dugaan yang memiliki nilai ke arah negatif; namun dapat pula dugaan ini bersifat positif. Tetapi pada umumnya mengarah pada penilaian negatif yang diwarnai oleh perasaan yang muncul sesaat itu". Liliweri (2003:15) mengungkapkan bahwa "prasangka adalah sikap antipati yang didasarkan pada kesalahan generalisasi atau generalisasi tidak luwes yang diekspresikan sebagai perasaan".

Berdasarkan hasil observasi dan wawancara, dalam hubungannya dengan kehidupan beragama di wilayah Kecamatan Cigugur, prasangka sosial antarkelompok keagamaan terjadi karena kurangnya informasi individu ataupun kelompok dalam memahami berbagai peristiwa keagamaan yang terjadi di wilayahnya. Masalah hubungan antakelompok keagamaan merupakan masalah rawan konflik yang menjurus kepada SARA. Secara umum di desa Cisantana hubungan antarkelompok keagamaan nampak baik, terutama dalam kegiatan sosial kemasyarakatan. Namun tidak berarti tidak ada masalah sama sekali dalam hubungan antarkelompok keagamaan, kecurigaan-kecurigaan memang tetap ada. Kondisi demikian perlu disikapi dengan bijaksana untuk tidak menimbulkan konflik. Pada sisi lain komunikasi antarkelompok keagamaan di lingkungan Lumbu Kelurahan Cigugur sebagaimana dikemukakan salah seorang informan menggunakan istilah “ti' is-ti' is jahe", ibarat api dalam sekam. Dipermukaan memang nampak harmonis. Hal ini terlihat dari kegiatan sosial kemasyarakatan seharihari. Tetapi dengan adanya prasangka antarkelompok jika ada saja propokator dari luar yang menyinggung masalah perbedaan agama, tidak menutup kemungkinan di Kelurahan Cigugur dapat terjadi konflik.

Dalam hubungannya dengan pengembangan sarana peribadatan, prasangka sosial antarkelompok keagamaan di Kecamatan Cigugur juga terjadi sebagaimana dikemukakan oleh salah seorang informan bahwa ada kekhawatiran akan adanya gerakan dan perkembangan Kristenisasi terutama menyangkut pembangunan Gua Maria yang berlokasi di blok Totombok satu kilometer dari dusun Malaraman Desa Cisantana yang penduduknya seluruhnya beragama Islam. Selain itu, mereka pun berusaha memiliki lahan-lahan disekitarnya dengan cara membeli dari pemiliknya meskipun dengan harga yang agak tinggi. Prasangka sosial juga terjadi dalam hal perluasan kepemilikan tanah dan pendirian sarana-sarana pendidikan yang berlatar belakang keagamaan, sebagaimana dikemukakan oleh salah seorang informan bahwa kepemilikan lahan di daerah Mayasih Kelurahan Cigugur banyak yang sudah dikuasai oleh mereka dan dijadikan komplek pendidikan dan asrama orang-orang Katolik. Pada sisi lain, kelompok keagamaan lainnya berupaya mendirikan lembaga pendidikan baik pendidikan formal maupun non-formal.

Prasangka sosial juga terjadi dalam posisiposisi tertentu di masyarakat seperti halnya Ketua RT (Rukun Tetangga) dan RW (Rukum Warga), mereka lebih cenderung mempertahankan posisi-posisi tersebut untuk diduduki oleh orang yang berasal dari kelompoknya. Dalam sektor perekonomian masyarakat pedesaan, prasangka sosial yang muncul sebagaimana dikemukakan oleh salah seorang informan bahwa masalah kegiatan ekonomi, terutamadalam hubungannya dengan KUD Dewi Sri, sebenarnya terjadi kecemburuan sosial antarkelompok kagamaan; terutama dari umat Islam sebab hampir seluruh pengurus KUD tersebut adalah umat Katolik; kalau toh ada orang Islam, hanya beberapa gelintir saja. Padahal justru anggota KUD tersebut sebagian besar merupakan orang-orang Islam. Mereka yang merasa tidak puas karena diperlakukan kurang adil, keluar dari keanggotaan koperasi tersebut dan membentuk kelompok usaha sendiri yang bergerak dalam bidang yang sama yakni koperasi "Laras Ati".

Dalam hal perpindahan agama juga merupakan sektor yang dapat menimbulkan adanya prasangka sosial. Perpindahan agama seseorang di wilayah Kecamatan Cigugur pada umumnya disebabkan oleh pernikahan. Sehubungan dengan prasangka sosial yang muncul sebagai akibat dari perpindahan agama dikemukakan oleh salah seorang informan:

Saya ditunjuk sebagai pembina kaum mualif untuk wilayah desa Cisantana. Pada umumnya mereka masuk Islam karena proses pernikahan. Sebelum pernikahan dilangsungkan, yang bersangkutan di-Islamkan dulu dengan meminta persetujuan dari pihak kepastoran di Cigugur. Pembinaan mualif mencakup akidah Islamiyah dan ahlak. Selain itu kita juga turut membantu pengembangan perekonomian mereka sesuai dengan bidangnya. Suatu hari pernah saya dilaporkan kepada pihak Koramil oleh salah seorang umat Katolik karena kecurigaan mereka dikiranya saya mengajak-ajak umat Katolik untuk masuk Islam dengan memberikan sejumlah 
bantuan. Saya menjelaskan kepada pihak Koramil bahwa saya tidak pernah mengajak umat lain untuk masuk Islam dengan cara apa pun. Tetapi saya hanya memberikan bimbingan dan pengarahan serta bantuan lainnya kepada mereka yang baru masuk agama Islam dan itu merupakan kewajiban saya.

Sebagaimana informasi yang dikemukakan oleh informan di atas, salah seorang informan lainnya pada kesempatan yang berbeda mengungkapkan Saya memang membina beberapa mualif. Mereka dibina dalam hal akidah Islamiyah dan secara ekonomi kita bantu. Pada umumnya mereka masuk Islam karena ikatan perkawinan. Pada awal mereka masuk Islam, mereka banyak mendapat tekanan baik dari keluarganya maupun dari kelompoknya. Nah mereka yang mendapat tekanan demikian kita berikan perlindungan. Biasanya saya menampung mereka di rumah saya kurang lebih sekitar satu minggu. Bagi laki-laki yang masuk Islam kita sunat dengan biaya dan pengurusan setelah sunat dari kita.

Berbagai prasangka sosial yang muncul antar kelompok keagamaan sebagaimana dikemukakan di atas menunjukkan bahwa meskipun hubungan antarkelompok keagamaan di Kecamatan Cigugur nampak harmonis, kecurigaan antarkelompok agama tetap terjadi. Prasangka sosial yang berkembang di antara kelompok keagamaan, menyebabkan hubungan antarkelompok keagamaan harmonis hanya nampak dipermukaannya saja. Adanya suatu kekhawatiran akan adanya penguasaan suatu kelompok keagamaan terhadap kelompok keagamaan lainnya, melalui penguasaan lahan-lahan yang dipandang strategis, pengembangan sarana-sarana peribadatan, pengembangan pendidikan yang berlatar belakang keagamaan, penguasaan sektor perekonomian, serta penguasaan posisi dan jabatan tertentu di masyarakat menyebabkan hubungan antarkelompok keagamaan, ibarat api dalam sekam. Kehidupan antarumat berbeda agama nampak rukun, namun saling memendam sikap curiga. Lukito (Majemuk no. 7 Januari-Februari 2004:11) mengungkapkan bahwa hal yang paling menakutkan di Indonesia adalah Kristenisasi. Identitas Kristen di Indonesia sering dikaitkan dengan dua hal, yakni misi dan kolonialisme Barat. Isu Kristenisasi pada umumnya bergerak seputar pertambahan jiwa, perbanyakan gereja, dan keikutsertaan umat Kristen dalam social progress dunia modern serta didukung oleh infra struktur modern barat seperti sekolah, rumah sakit dan media massa, menyebabkan Kristenisasi seperti arus tak terbendung.

Sejalan hal tersebut, kekhawatiran umat Islam di Kecamatan Cigugur atas mobilisasi Kristen melalui pembangunan sarana peribadatan, sarana pendidikan, sarana perekonomian yang didukung oleh media massa merupakan faktor yang dominan bagi terbentuknya sikap prasangka sosial dalam pluralitas keberagamaan. Sikap prasangka tersebut melahirkan perilaku reaktif ketika mereka melihat pengembangan sarana peribadatan dan pendidikan serta penguasaan sektor ekonomi pedesaan melalui Koperasi Unit Desa (KUD) oleh salah satu kelompok keagamaan sebagaimana dikemukakan di atas. Hal tersebut menunjukkan bahwa hubungan antarkelopok keagamaan di Kecamatan Cigugur memiliki potensi yang cukup kuat untuk terjadinya konflik. Namun melalui pengembangan sikap saling menghargai, pengendalian diri, tolong menolong, kebersamaan dalam kegiatan sosial kemasyarakatan dan melalui kerja sama yang saling menguntungkan, prasangka sosial yang berkembang dalam suatu kelompok keagamaan terhadap kelompok keagamaan lainnya dapat diminimalisasi, sehingga konflik secara terbuka antarkelompok keagamaan di Kecamatan Cigugur dapat dihindarkan. Sebagaimana dikemukakan oleh beberapa informan bahwa kehidupan antarkelompok keagamaan di Cigugur meskipun diwarnai oleh berbagai prasangka, tidak akan terjadi konflik keagamaan. Konflik tersebut hanya akan terjadi jika ada orang-orang dari luar yang dengan sengaja melakukan penghasutan sehubungan dengan kehidupan kelompok keagamaan. Jadi selama tidak ada pihak-pihak dari luar yang turut campur dalam kehidupan sosial keagamaan, di Cigugur tidak akan terjadi konflik.

Samovar et.al. (1981:124) mengungkapkan bahwa perwujudan sikap prasangka antara lain: 1) Antilocution, yakni mendiskusikan kelompok lain dari sisi negatifnya; 2) Avoidance, merupakan upaya menghindar dari kelompok lain yang tidak disukai; 3) Discrimination, yaitu mengucilkan kelompok tertentu yang dianggap tidak layak untuk diajak berkomunikasi; 4) Violence, merupakan serangan fisik setelah emosi meningkat; dan 5) extermination merupakan upaya pemusnahan satu persatu atau secara masal. Dengan demikian, adanya sikap prasangka sosial akan menjadi sumber yang potensial bagi perpecahan/disintegrasi yang dapat mengakibatkan terjadinya konflik. Berdasarkan temuan penelitian, kecurigaan-kecurigaan antar kelompok keagamaan memang tetap terjadi, namun melalui sikap yang arif, kecurigaan-kecurigaan antarkelompok keagamaan yang muncul tidak menyebabkan munculnya konflik, tetapi sebaliknya lebih membuat masing-masing kelompok keagamaan untuk tetap mawas diri dengan meningkatkan sikap saling mempercayai antarkelompok keagamaan, sebab pada dasarnya setiap kelompok keagamaan menginginkan hidup rukun dan damai berdampingan dengan kelompok keagamaan yang lainnya dalam tatanan hidup bermasyarakat. Menyadari akan hal demikian, masyarakat Cigugur selalu berhati-hati ketika prosesproses komunikas memasuki wilayah keagamaan dan kehati-hatian mereka juga terjadi dalam mensikapi orang yang baru mereka kenal (terutama para mubaligh, pastor, pendeta) di wilayahnya yang memberikan ceramahceramah keagamaan. Ketika pembicaraan sudah menyangkut hubungan antarkelompok keagamaan, apalagi dalam pandangan mereka kelompok yang satu menjelekkan kelompok yang lainnya dengan cara dan 
gaya yang bagaimana pun, sikap mereka akan cenderung lebih berhati-hati untuk tidak menimbulkan konflik antarkelompok keagamaan.

Prasangka sosial antarkelompok keagamaan terjadi biasanya diawali oleh prasangka yang muncul dari diri individu dan individu yang bersangkutan mengembangkan prasangka tersebut pada kelompoknya. Sebagaimana dijelaskan oleh Krech at.al., (1962:186), "informasi yang menyebabkan terbentuknya sikap akan berhubungan dengan sikap-sikap yang lainnya”. Hal tersebut juga menunjukkan bahwa sikap individu yang bersangkutan dibentuk oleh afiliasi kelompoknya. Karenanya sikap individu akan mencerminkan sikapsikap kelompoknya. Dengan demikian sikap prasangka sosial yang muncul dalam diri individu atas suatu persitiwa akan mudah berkembang dalam kelompoknya, apalagi jika individu yang bersangkutan memiliki pengaruh yang cukup kuat terhadap kelompoknya.

Berdasarkan uraian di atas, prasangka sosial yang berkembang di antara kelompok keagamaan terjadi karena adanya suatu kekhawatiran akan adanya penguasaan suatu kelompok keagamaan terhadap kelompok keagamaan lainnya melalui: 1) Penguasaan lahan-lahan yang dipandang strategis, 2) Pengembangan sarana-sarana peribadatan, 3) Pengembangan pendidikan yang berlatar belakang keagamaan, 4) Penguasaan sektor perekonomian, 5) Penguasaan posisi dan jabatan tertentu di masyarakat, dan 6) Perpindahan agama. Dengan demikian, prasangka sosial dalam pluralitas keberagamaan di Kecamatan Cigugur Kabupaten Kuningan Jawa Barat dapat diilustrasikan sebagai berikut:

\section{SIMPULAN}

Dalam hubungannya dengan kehidupan beragama di wilayah Kecamatan Cigugur, prasangka sosial dalam pluralitas keberagamaan terjadi karena kurangnya informasi individu ataupun kelompok dalam memahami berbagai peristiwa keagamaan yang terjadi di wilayahnya. Prasangka sosial antarkelompok keagamaan terjadi biasanya diawali oleh prasangka yang muncul dari diri individu dan individu yang bersangkutan mengembangkan prasangka tersebut pada kelompoknya.

Prasangka sosial dalam pluralitas keberagamaan terjadi karena adanya suatu kekhawatiran akan penguasaan suatu kelompok keagamaan terhadap kelompok keagamaan lainnya melalui: 1) Penguasaan lahan-lahan yang dipandang strategis, 2) Pengembangan saranasarana peribadatan, 3) Pengembangan pendidikan yang berlatar belakang keagamaan, 4) Penguasaan sektor perekonomian, 5) Penguasaan posisi dan jabatan tertentu di masyarakat, dan 6) Perpindahan agama.

Prasangka sosial yang berkembang dalam suatu kelompok keagamaan terhadap kelompok keagamaan lainnya dapat diminimalisasi melalui pengembangan sikap saling menghargai/toleransi, pengendalian diri, tolong menolong, tanggung jawab bersama dalam kegiatan sosial kemasyarakatan dan melalui kerja sama yang saling menguntungkan sehingga konflik secara terbuka antarkelompok keagamaan di Kecamatan Cigugur dapat dihindarkan.

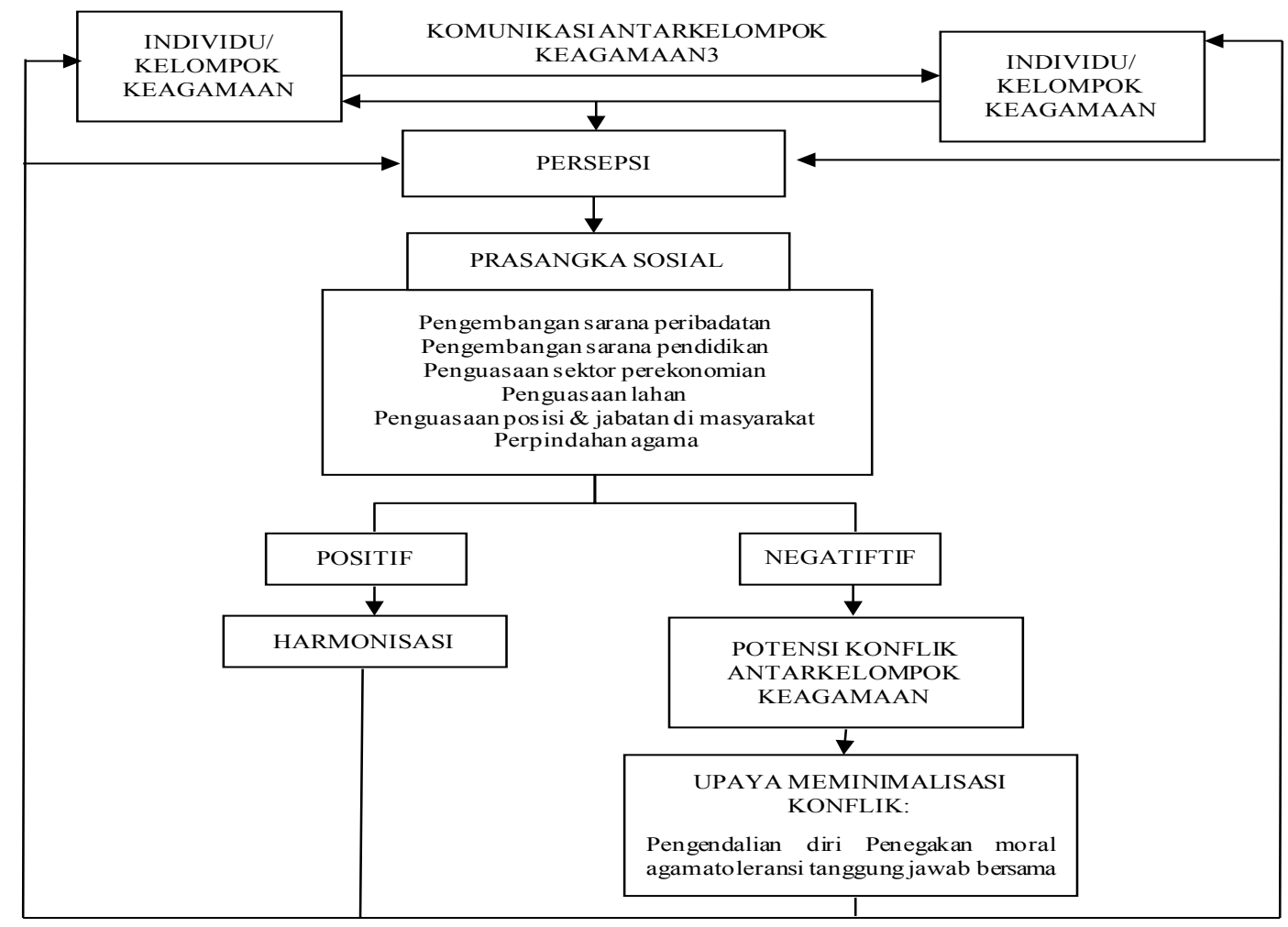

Gambar 2. Prasangka sosial dan upaya meminimalisasi konflik dalam pluralitas keagamaan di Kecamatan Cigugur Kabupaten Kuningan Jawa Barat 


\section{DAFTAR PUSTAKA}

Goddard, Hugh, 2000. Menepis Standar Ganda: Membangun Saling Pengertian Muslim-Kristen. Penerjemah: Ali Noer Zaman. Yogyakarta: Qalam.

Krech, David; Richard S. Crutchfield; dan Egerton L. Ballachey. 1962. Individual in Society: A Texbook of Social Psychology. Tokyo: McGraw Hill.

Liliweri, Alo. 2003. Makna Budaya dalam Komunikasi Antar Budaya. Yogyakarta: LkiS

Lutan, Rusli. 2001. Keniscayaan Pluralitas Budaya Daerah: Analisis Dampak Sistem Nilai Budaya Terhadap Eksistensi Bangsa. Bandung: Angkasa.

Mar'at, 1982. Sikap Manusia Perubahan serta Pengukuran. Jakarta: Ghalia Indonesia.

Miles, Matthew B dan Huberman, A Michael. 1992. Analisis Data Kualitatif. Jakarta. Universitas Indonesia Press.

Moleong, Lexy J., 1990. Metodologi Penelitian Kualitatif. Bandung: Rosdakarya.
Mulyana, Deddy., 2001. Nuansa-Nuansa Komunikasi: Meneropong Politik dan Budaya Komunikasi Masyaarakat Kontemporer. Bandung: Remaja Rosda Karya.

Mulyana, Deddy., 2002. Ilmu Komunikasi: Suatu Pengantar. Bandung: Remaja Rosda Karya.

Nasikun, 1995. Sistem Sosial di Indonesia. Jakarta: Raja Grafindo Persada.

Newcomb, Theodore. M. et. All. Social Psychology: The Study of Human Interaction. Holt Rinehart and Winston Inc. New York, Chicago. San Francisco, Toronto, London. Alih Bahasa Noesjirwan Joesoef, dkk. 1985. Psikologi Sosial. Diponegoro. Bandung.

Purwasito, Andrik. 2003. Komunikasi Multikultural. Surakarta: Muhammadiyah University Press.

Samovar, et.al., 1981. Understanding Intercultural Communication, Belmont - California: A Division Of Wadsworth Inc.

Lukito: Majemuk: Merayakan Perbedaan, Buletin edisi no. 7 Januari - Februari 2004. Jakarta: Indonesian Conference on Religiopn and Peace. 